\title{
Opportunities for Decentralization in a Pandemic Year: What Does Budget Analysis Show?
}

\author{
N. V. Zubarevich ${ }^{a, b}$, * \\ a Moscow State University, Faculty of Geography, Moscow, 119991 Russia \\ ${ }^{b}$ Russian Presidential Academy of National Economy and Public Administration, Moscow, 119571 Russia \\ *e-mail: nzubarevich@gmail.com
}

Received March 5, 2021; revised April 3, 2021; accepted April 21, 2021

\begin{abstract}
In the year of the pandemic, assistance to Russian regional budgets increased by more than 1.5 times, which ensured an increase in budget revenues in the vast majority of regions, but led to a significant increase in dependence on federal assistance. In the structure of aid, the share of targeted transfers (subsidies and subventions) increased, so the possibility of maneuvering budget resources for regions has decreased. Regions are forced to spend additional aid mainly on top-prescribed goals, which has led to a further increase in centralization of management. The transparency of allocation of transfers to regions worsened, and the amount of additional aid did not depend on the reduction of own revenues of regional budgets. Before the pandemic, priority "geopolitical" regions had received special support; for 2020, it is much more difficult to explain the distribution of aid due to the uncoordinated allocation of transfers by different federal ministries for different purposes. In the past, budgetary federalism in Russia had manifested itself only in a certain freedom of choice by the regional authorities in spending priorities, but in 2020, this was even less. Health care and, almost everywhere, social security of the population became an overall priority, since transfers were significantly added for these purposes. Regarding other types of expenditures, the priorities of regions differed, but most of them subsidized fees for housing and communal services and increased spending on the national economy to meet the targets of the presidential decree. Hopes for decentralization of the Russian system of government during the pandemic were not realized; in interbudgetary relations, the degree of regional dependence on the federal authorities increased.
\end{abstract}

Keywords: pandemic, COVID-19, regional budgets, transfers, budget deficit, health care costs, regional debt, Russia

DOI: $10.1134 /$ S2079970521030138

\section{INTRODUCTION AND FORMULATION OF THE PROBLEM}

In 2020, there were numerous statements about the highlighted turn towards decentralization of the Russian system of governance, since some powers to combat the pandemic were transferred by the federal authorities to the regional level. Talk even began about strengthening federalism, although this presupposes significant autonomy of regions in decision making, clearly allocated powers, and provision of financial resources for their implementation. The power vertical built in Russia poorly meets these criteria.

What changed in the year of the COVID-19 pandemic? To assess possible shifts towards decentralization, first of all, it is necessary to consider interbudgetary relations between the center and regions: it is money, not words, that serves as a "litmus test" for analyzing changes. Obviously, restrictions on business activities and decrease in demand during the pandemic had a negative impact on the dynamics of budget revenues at all levels. In addition, regional budgets required additional assistance to increase spending on health care and social security of the population. The negative balance for regional budgets-a decrease in revenues and the need for increased spending-immediately casts doubt on talk about decentralization and strengthening of federalism in Russia.

This article addresses the following issues:

- How did the pandemic affect regional budget revenues and which regions were hit harder?

- How has the dependence of regional budgets on federal aid changed?

- Has there been a shift towards more transparent intergovernmental fiscal relations consistent with a federated structure?

- Is it possible to identify the priorities of assistance to the regions in the year of the pandemic, depending on various factors (level of development, budgetary provision, geographic location, etc.)?

- Have regions become more independent in making decisions on expenditure policy in the year? 


\section{REVIEW OF EARLIER RESEARCH}

Among numerous foreign studies on budgetary federalism and geography of public finance, the first fundamental analysis of interbudgetary relations (Bennett, 1980), which explained the need for decentralization, and research on territorial justice (Boyne and Powell, 1991) set the conceptual framework for analyzing interbudgetary relations in Russia and problems of territorial justice, which are always aggravated in crises.

During the pandemic, the term "coronationalism" even appeared, which reflects the strong dominance of national governments over regional and local authorities and international organizations (Bouckaert, et al., 2020). The degree of centralization varied. For example, in Germany, a number of measures were taken to centralize the management system in the COVID crisis, but they were limited; further efforts to centralize the country at the expense of competence of the federal states undertaken during the crisis by the federal government and, especially, the federal ministry of health, failed (Franzke, 2020).

Foreign publications dealing with the problems of subnational budgets in the COVID crisis were mostly made "hot off the assembly line," with minimal quantitative analysis. In addition, they often deal with the budgetary problems of municipalities. For Germany's municipalities, the problems of decreased revenues and increased expenditures and debts of municipalities are listed, but analysis of the data is lacking (Franzke, 2020). A study of the resilience of urban and rural municipalities in Hungary during the pandemic, conducted through telephone interviews with leaders, showed that the level of financial support from the central authorities was insufficient in the face of decreasing municipal revenues and the need to increase spending. The financial sustainability of municipalities was assessed on a five-point scale; in cities, the lack of funds was more significant than in rural municipalities (3.4 and 2.9 points, respectively) (Finta et al., 2020). At the same time, the survey did revealed no growth in contradictions in the centralized system of relations between central and local authorities during the pandemic. A UK study lists the amount of different types of financial assistance to regions of England during the pandemic. Besides, additional assistance allocated from the central budget of Great Britain and the budget of England (for its regions) per capita was calculated. Scotland and Wales received the most, Northern Ireland received the least, and the Northwest led among the regions of England (Gore et al., 2021). The article does not explain these differences.

A review of the studies by Russian economists and geographers includes only studies that analyzed the state of Russian regional budgets in different crisis periods from 2009 to 2020. The transformation of interbudgetary relations in the 2009 crisis considered by O.V. Kuznetsova (2010) shows changes in the structure of budget expenditures, as well as the features of expanded tax powers of regional budgets during the crisis. The author of this article analyzed the structure of regional budget expenditures during the crisis, the volume of budgetary support to regions, and the instruments, the main of which was an increase in transfers, primarily subsidies to ensure balanced budgets and support for employment (Zubarevich, 2011). The budgetary policy features during this crisis were studied in more detail with a case study of six regions; it was shown that it did little to contribute to postcrisis modernization of their economies (Starodubovskaya et al., 2010).

The state of regional budgets during the 2015 crisis was analyzed during monitoring of the Development Center of the Higher School of Economics and Institute for Social Analysis and Forecasting (INSAP) of RANEPA. Broader objectives were set in scientific articles. The dynamics of budget revenues and regional economic indicators influencing tax revenues were compared (Zubarevich, 2015). The dynamics and structure of social expenditures in the regions, not only for the crisis year, were analyzed, the distribution of budgetary obligations between the federal government and the regions in the implementation of decrees on wage increase, it was concluded that the decrease in the budgetary stability of the regions mainly occurred for this reason, and not as a result of the crisis (Zubarevich and Gorina, 2015).

The state of regional budgets for different months of 2020 was considered in monitoring by the Institute for Development of the Higher School of Economics (Chernyavsky, 2020a, b, 2021) and monitoring by INSAP RANEPA, published in the journal Economic Deve-lopment of Russia (Khasanova et al., 2020; Khasanova and Zubarevich, 2021; Makarentseva et al., 2020 ), as well as in the studies by A. Deryugin, also published in this journal (Deryugin, 2020a, b). In all works, the main trends are highlighted-a strong decline in budget revenues during the lockdown period and a very significant increase in federal aid to the regions. An analysis of the results of 2020 is presented in (Chernyavsky, 2021), but in general for all regions with a listing of the most problematic for individual budget indicators and without comparison with changes throughout the year. A comparative analysis of regional budget revenues in the first months of the pandemic and in previous crises of the 2000s was also done (Zubarevich and Safronov, 2020). It showed that the drop in spring 2020 was the strongest due to the lockdown. The article by M. Mil'chakov (2020), prepared at the beginning of the first wave of the pandemic, examines scenarios of budget losses and the possibility of implementing national projects, taking into account the growth of budget expenditures for combating coronavirus infection. The author notes that pre-COVID implementation of national projects accounted for about one-third of budgetary alloca- 
Table 1. Dynamics of consolidated budget revenues of regions in 2020, in $\%$ to the same period of 2019

\begin{tabular}{l|c|c}
\hline \multicolumn{1}{c|}{ Type of reveue } & $\begin{array}{c}\text { April-June 2020 } \\
\text { to April-June 2019, \% }\end{array}$ & $\begin{array}{c}\text { January-December 2020 } \\
\text { to January-December 2019, \% }\end{array}$ \\
\hline All revenues & -5 & 10 \\
Tax and nontax revenue, incl. & -20 & -2 \\
$\quad$ profit tax & -27 & -13 \\
personal income tax & -10 & 7 \\
small business income taxes & -28 & -1 \\
Interbudgetary transfers & 73 & 54 \\
\hline
\end{tabular}

Source: calculated from Federal Treasury data.

tions in the total volume of interbudgetary transfers to the budgets of federal subjects.

The listed publications are important for understanding the budgetary problems of regions during the 2020 pandemic, but they do not address the question: how has Russian budget policy changed-towards decentralization or further centralization?

\section{DATA SOURCES AND METHODS}

The analysis was carried out based on monthly data of the Federal Treasury on execution of the consolidated budgets of regions for 2020 and in previous years in order to calculate the dynamics. We considered all revenues of regional budgets, tax and nontax revenues (without transfers), which are often called own revenues, as well as the volume and dynamics of transfers (gratuitous aid), including their individual types: grants, subsidies, subventions and other interbudgetary transfers. These types of transfers differ. Grants can be spent freely by regions (although in the year of COVID, part of the grants were allocated for health care). Subsidies were allocated for specific purposes designated by the federal authorities, and regions had to cofinance them by adding funds to their budgets. Subventions are funds for the fulfillment of federal powers (payment of unemployment benefits and many others). Other intergovernmental transfers are also mainly targeted. Thus, only grants (and not all of them in the year of the pandemic) do not have clear spending targets; i.e., they are "not colored" and can be freely used by regions.

Budget expenditures were analyzed as a whole for 2020 and 2019 to calculate the dynamics. A functional classification of expenditures was used, which allows us to consider their main types: from the national economy and housing and communal services to the main types of social expenditures (education, health care, social policy, etc.). The author's long-term analysis of regional budget expenditures has shown that it is necessary to separate the budget expenditures of Moscow and all other regions, since their structure and dynamics are very different.
Russian budget analysis does not apply adjustments to the dynamics of revenue and expenses for inflation; therefore, calculations of the dynamics are given in nominal rubles. The article uses simple statistical methods for analyzing the dynamics and structure of budget indicators, which make it possible to obtain significant answers to the questions posed.

\section{RESEARCH RESULTS}

\section{During the Pandemic, the Budgets of More Developed Regions, Especially Oil and Gas Producing Regions, Suffered the Most, which Reduced Their Budgetary Provision.}

In the first wave of the pandemic, over the 3 months of lockdown (April-June), budget revenues in almost all regions decreased significantly due to a decrease in the revenues of the two most important taxes for regions: on personal income (personal income tax) and profit tax paid by business (Table 1). Performance for the whole year is much better, although the loss of profit tax remains significant. This tax is most important for the budget revenues of resource-producing regions, especially oil and gas and partly coal. The strongest decline in profit tax revenues (by 38-52\% in 2020) was observed in the Yamalo-Nenets and Nenets autonomous okrugs; the republics of Tatarstan, Komi, and Bashkortostan; Perm Krai; and Tyumen, Kemerovo, and Astrakhan oblasts. Personal income tax revenues increased due to the large share of those employed in the public sector and at state-owned enterprises, where earnings were indexed. The underemployment growth (and, as a consequence, decline in wages) at the medium-sized enterprises and organizations was short-term, mainly in the second quarter of the lockdown period. Even income tax paid by small businesses fell by only $1 \%$ overall over the year. Own (tax and nontax) revenues of regional budgets, despite the spring failure, in general decreased over the year by only $2 \%$, but in oil and gas producing regions, the decline was much stronger, by $12-24 \%$. 


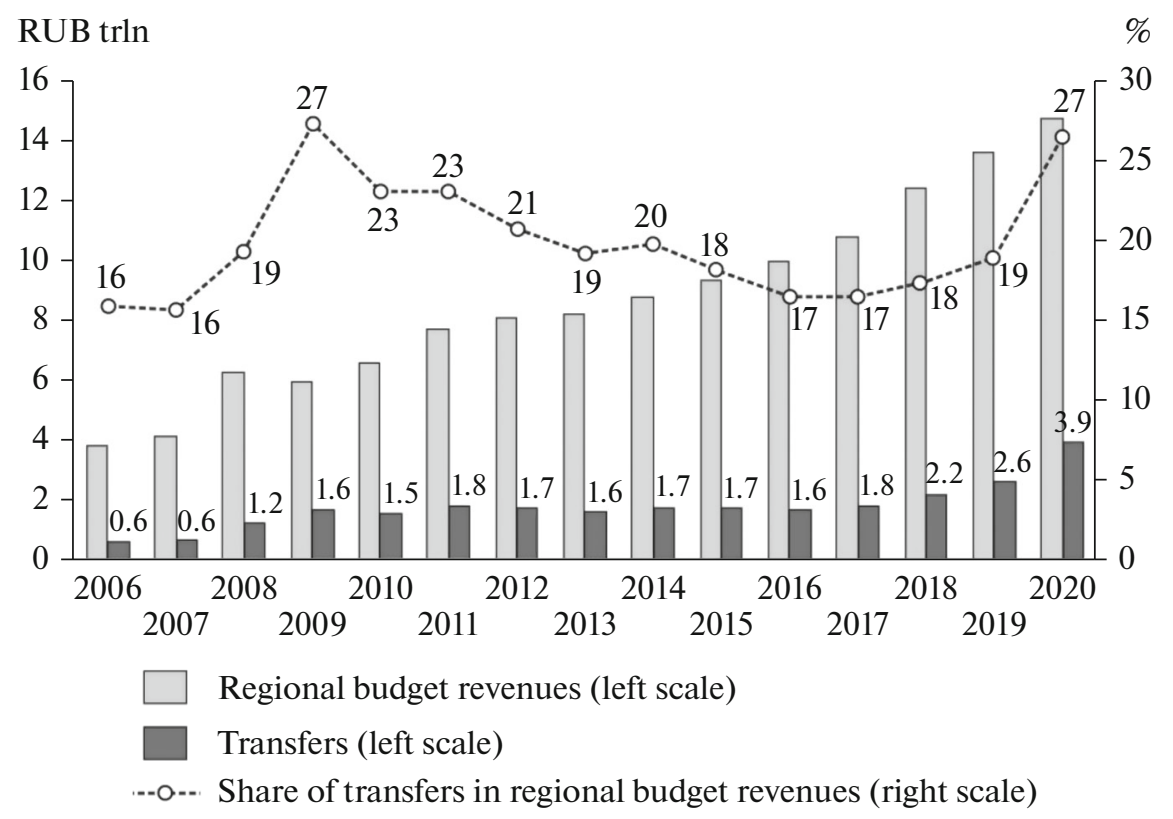

Fig. 1. Revenues of consolidated budgets of regions, all transfers (RUB trln)* and their share in budget revenues (\%). *2014-2016-without Crimea and Sevastopol.

Source: calculated from Federal Treasury data.

\section{Assistance to Regions in the Pandemic Grew Unprecedentedly, More Than 1.5 Times; There Was no such Growth in Transfers for the Entire Post-Soviet Period That Led to Increased Dependence of Regional Budgets on the Federal Center}

Aid began to increase rapidly in the very first months of the pandemic; in the second quarter of 2020, transfers increased by three-quarters and went mainly towards health and social protection. For the whole of 2020, regions received more than RUB $1.3 \mathrm{trln}$; additionally, the volume of interbudgetary transfers increased by 54\%; all transfers, by more than 1.5 times and approached RUB 4 trln. The 2009 crisis was also accompanied by a strong decrease in income tax revenues and own revenues of budgets of many regions, but then the volume of transfers increased by $34 \%$. Both crises are similar to strong growth not only in the volume of transfers, but also in the level of transfers in regional budgets total revenues-from 19 to 27\% (Fig. 1).

The dependence of regional budgets on transfers in 2020 increased in all regions, with the exception of Moscow, Khanty-Mansi Autonomous Okrug, Sakhalin Oblast, and Chukotka Autonomous Okrug, due to the specifics of federal policy. The strongest growth in subsidies took place in the relatively developed and moderately developed regions of the Volga, Siberian, the Northwestern federal districts, and partially in the Center and the Urals. Previously, they were not recipients of large-scale aid, but in 2020 they "sagged" more in terms of their own budget revenues (Fig. 2). Compared to 2018 and 2019, when subsidies also grew due to additional financing of national projects from the federal budget, the rate of growth in 2020 is much higher. Less significant changes in highly subsidized regions are explained arithmetically: the growth of transfers was accompanied by nearly the same growth in budget revenues and the proportion changed little. It is possible to note only a significant increase in the level of subsidies in Dagestan and Sevastopol, which received a very large volume of additional transfers.

\section{In the Structure of Transfers, Targeted Types of Aid Were the Fastest-Growing, Which Reduced the Independence of Regions in the Maneuver of Budget Resources, Additional Aid Was Spent Mainly on What Was Prescribed From Above}

The dynamics of certain types of transfers (Table 2) is due to various factors. The outstripping growth in subsidies is partly a consequence of an increase in assistance to regions for payment of social benefits for children (for the birth of a third child and children up to 3 years of age, as well as a new benefit for children from 3 to 7 years old). In total, these two subsidies accounted for more than a quarter of all subsidies received by regions in 2020 . The remaining subsidies were mainly used to cofinance the implementation of national projects. Other interbudgetary transfers, like subsidies, were allocated for specific purposes; they have grown by almost 1.5 times.

The growth of subventions is largely due to the labor market crisis during the pandemic. The payment of unemployment benefits is a federal power; volume 


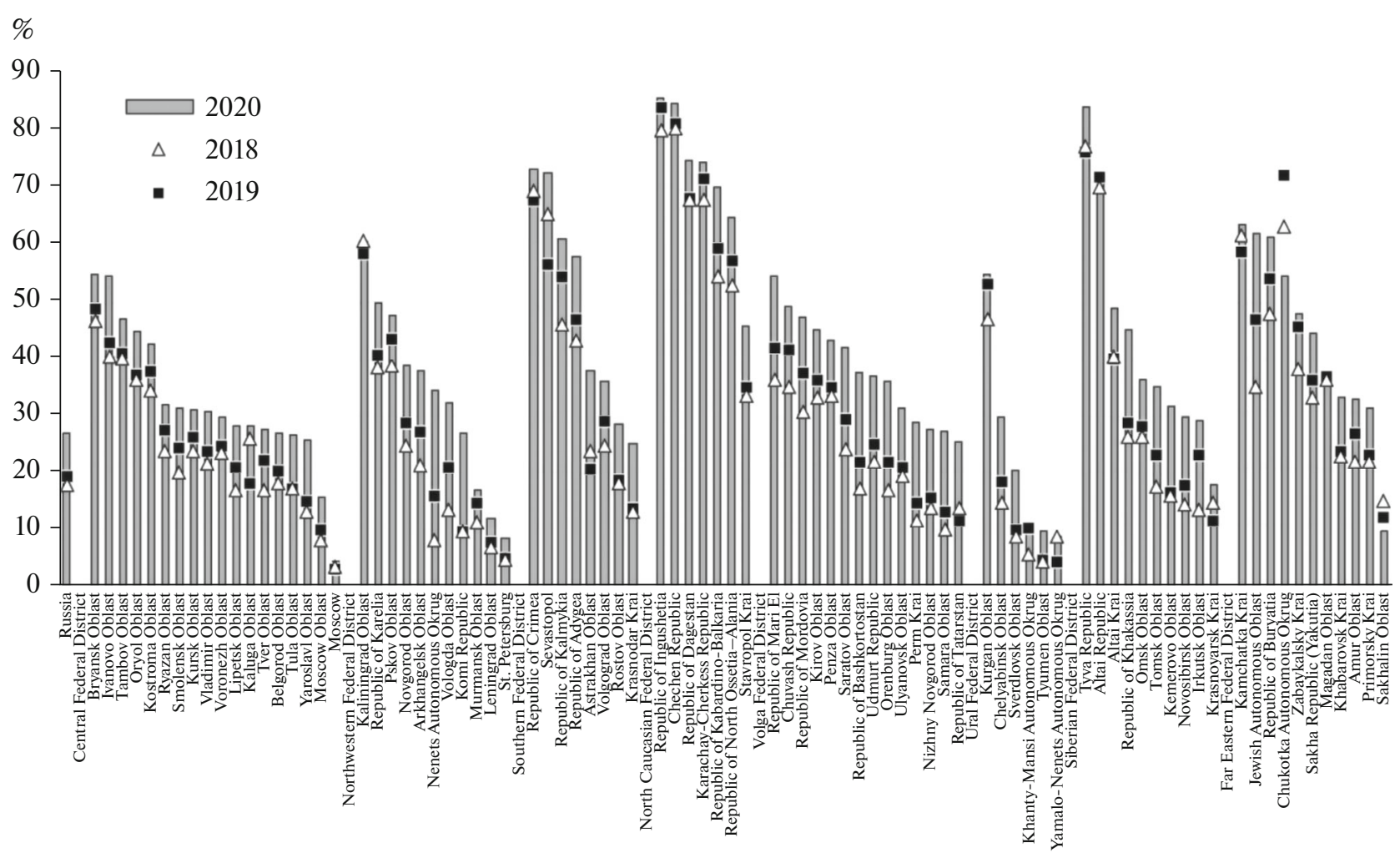

Fig. 2. The share of transfers in the revenues of the consolidated budgets of the regions, $\%$. Source: calculations based on data from the Federal Treasury.

almost doubled (from RUB 104 bln in 2019 to RUB 197 bln in 2020) and accounted for a third of all subventions. At the same time, the level of registered unemployment from March to September 2020 increased five times, which was facilitated by an increase in the amount of unemployment benefits and simplified registration with employment services. However, by the end of 2020, the number of registered unemployed decreased by one-third due to improvement in the economic situation and for institutional reasons: since October, the minimum amount of ben- efits was reduced to RUB 1500 , and registration of the unemployed became stricter.

Equalization grants are calculated according to a formula and are relatively stable; their volume increased by only $6 \%$. It is up to regions how to use these funds. Balance grants are the most opaque in terms of allocation criteria; their volume varies greatly from year to year. In 2020, a 2.3-fold increase in subsidies for balancing was partly a consequence of the pandemic: about RUB 90 bln were added to healthcare (deployment of beds, purchase of equipment, additional payments to doctors and healthcare work-

Table 2. Volume and dynamics of transfers from other budgets of budgetary system with allocation of certain types of transfers

\begin{tabular}{l|r|r|r|r|l|l|r|r}
\hline \multirow{2}{*}{\multicolumn{1}{c|}{ Indicator }} & \multicolumn{3}{c|}{ Volume, RUB bln } & \multicolumn{3}{c|}{ Share, \% } & \multicolumn{2}{c}{ Dynamics (growth), \% } \\
\cline { 2 - 8 } & 2018 & 2019 & 2020 & 2018 & 2019 & 2020 & 2019 to 2018, \% & 2020 to 2019, \% \\
\hline Transfers from other budgets incl.: & 2085 & 2453 & 3776 & 100 & 100 & 100 & 18 & 54 \\
Grants, total, incl.: & 1035 & 924 & 1304 & 49.6 & 37.7 & 34.5 & -11 & 41 \\
$\quad$ equalization grants & 644 & 675 & 718 & 30.9 & 27.5 & 19.0 & 5 & 6 \\
$\quad$ grants for balance, etc. & 391 & 249 & 586 & 18.8 & 10.2 & 15.5 & -36 & 136 \\
Subsidies & 384 & 557 & 1012 & 18.4 & 22.7 & 26.8 & 45 & 82 \\
Subventions & 332 & 397 & 606 & 15.9 & 16.2 & 16.0 & 20 & 53 \\
Other interbudgetary transfers & 334 & 575 & 854 & 16.0 & 23.4 & 22.6 & 72 & 48 \\
\hline
\end{tabular}

Source: calculated from Federal Treasury data. 
Table 3. Difference between own (tax and nontax) revenue of the consolidated budgets of regions and the volume of additional transfers, 2020 compared to 2019, RUB bln

\begin{tabular}{|c|c|c|c|c|c|}
\hline \multirow[b]{2}{*}{ Region } & \multicolumn{2}{|c|}{ Minimal assistance } & \multirow[b]{2}{*}{ Region } & \multicolumn{2}{|c|}{ Maximum assistance } \\
\hline & $\begin{array}{c}\text { change in own } \\
\text { revenue }\end{array}$ & $\begin{array}{l}\text { additional } \\
\text { transfers }\end{array}$ & & $\begin{array}{c}\text { change in own } \\
\text { revenue }\end{array}$ & $\begin{array}{c}\text { additional } \\
\text { transfers }\end{array}$ \\
\hline Tyumen Oblast & -56.1 & 7.1 & Moscow Oblast & 15.9 & 50.2 \\
\hline Yamalo-Nenets Autonomous Okrug & -39.1 & 8.6 & Krasnodar Krai & -26.3 & 46.8 \\
\hline Sakhalin Oblast & -14.5 & -6.8 & Republic of Bashkortostan & -22.9 & 45.1 \\
\hline Nenets Autonomous Okrug & -4.9 & 4.4 & Republic of Dagestan & 3.0 & 43.5 \\
\hline Republic of Tatarstan & -43.3 & 47.4 & Sverdlovsk Oblast & -3.9 & 39.5 \\
\hline Kemerovo Oblast & -24.1 & 31.1 & Amur Oblast & -3.9 & 38.8 \\
\hline Perm Krai & -21.7 & 27.2 & Novosibirsk Oblast & 1.8 & 33.7 \\
\hline Komi Republic & -14.5 & 17.8 & Republic of Crimea & -1.2 & 33.6 \\
\hline Arkhangelsk Oblast & -8.2 & 13.6 & Sakha Republic (Yakutia) & -6.1 & 32.3 \\
\hline Astrakhan Oblast & -6.8 & 12.1 & Rostov Oblast & 5.0 & 30.9 \\
\hline Karachay-Cherkess Republic & 0.2 & 4.0 & Chechen Republic & 1.4 & 28.1 \\
\hline Kurgan Oblast & 1.9 & 3.9 & St. Petersburg & 6.0 & 24.5 \\
\hline Khanty-Mansi Autonomous Okrug & 6.7 & -0.8 & Voronezh Oblast & 11.3 & 14.8 \\
\hline
\end{tabular}

Source: calculated from Federal Treasury data.

ers), with an overall increase in this type of subsidies by RUB 337 bln. Balance grants serve as a tool for both force majeure spending (increase in times of crisis) and the implementation of geopolitical priorities (a significant amount goes to Chechnya, Crimea, and Sevastopol).

Thus, the growth in the volume of transfers due to subsidies, subventions, and other interbudgetary transfers, as well as part of the grants aimed at healthcare, reduced the autonomy of regional authorities in making decisions. Transfers that the regions could spend independently by choosing priorities grew much more slowly.

\section{The Transparency of Aid to Regions during the Pandemic Has Worsened due to the Uncoordinated Policy of Federal Authorities and Growth of Lobbying}

Transfers to regions are allocated not only by the Ministry of Finance, but also other federal agencies. Coordination of aid from federal agencies has clearly deteriorated in the year of the pandemic; this is shown by the ratio of regional budget losses (shortfall revenues, i.e., the difference between tax and nontax revenues in 2020 compared to 2019) and the volume of additional transfers in 2020 compared to 2019.

The largest losses (lost revenue) with a small volume of additional transfers are in the oil and gas producing Yamalo-Nenets and Nenets autonomous okrugs, as well as in Tyumen Oblast; reduction in transfers with a decline in revenues is observed in Sakhalin Oblast (Table 3). In 2019, these regions had high budgetary sufficiency, and their per capita budget revenues adjusted for the budget expenditure index were $60 \%$ higher than the average for Russian regions. Weak federal aid means only one thing for them: they will have to "exit" at the expense of their own budgetary resources. However, in the group of victims, there are eight more regions poorly compensated for by "lost" budget revenues. Among them is not only the Republic of Tatarstan, in which budgetary provision in 2019 was $20 \%$ higher than the average for Russian regions, but also regions with low per capita budget revenues, which do not have budgetary resources to increase budgetary expenditures during a pandemic. It is not possible to explain why they were given so few transfers.

The list of regions that received the maximum additional assistance is even less explainable: more than half of them had no decline in own revenues. Comparison of the republics of Tatarstan and Bashkortostan is the most revealing: the first was barely covered by transfers of lost revenue, and the second was doubled. It has become even more difficult to explain the differentiation of the allocation of transfers to federal subjects in the year of the pandemic than in previous years. Most likely, this is a consequence of the lack of synchronicity in the actions of different federal ministries to allocate transfers to the regions and the lack of interdepartmental coordination. In addition, it is necessary to take into account how the transfers were distributed in the 2019. 
Table 4. Dynamics of expenditures of consolidated budgets of regions in 2020, in \% to 2019

\begin{tabular}{l|c|c|c}
\hline \multicolumn{1}{c|}{ Indicator } & All regions & Moscow & Regions without Moscow \\
\hline Total expenses, incl.: & 15 & 12 & 16 \\
Government issues & 11 & 26 & 9 \\
National economy & 8 & 9 & 8 \\
Housing and communal services, & -3 & -22 & 8 \\
incl. built environment improvement & -7 & -20 & 10 \\
Education & 6 & 6 & 6 \\
Healthcare & 72 & 101 & 64 \\
Social policies & 24 & 14 & 26 \\
\hline
\end{tabular}

Source: calculated from Federal Treasury data.

\section{Decentralization Remained only in Some "Freedom of Maneuver" When the Regional Authorities Chose the Priorities of Budget Expenditures, but the Outstripping Growth of "Targeted" Transfers Reduced These Opportunities}

Having received a large volume of additional transfers, mainly for the purposes prescribed from above, the regions increased the expenditures for which they received additional funds. The main priority is healthcare: on average across regions, expenditures on this item increased by $72 \%$, including in Moscow-more than doubled, and excluding Moscow-by $64 \%$ (Table 4). The second priority is social policy (social security of the population); the growth of these expenses is due to transfers for payment of additional benefits for children and unemployment. As a result, the federal authorities in the year of COVID influenced the expenditure priorities of regional budgets all the more strongly.

However, some degree of freedom in spending policy still remained. How was it used? Significant differences can be noted in the priorities of Moscow and other regions. The wealthy capital has significantly reduced the cost of the urban environment improvement (they had accounted for two-thirds of all expenses for housing and communal services). Moscow has also been slower to increase spending on social policy (social secutiry of the population), since a significant part of these expenditures consists of stable payments of Moscow pension supplements $(5.5 \%$ of all Moscow budget expenditures in the last two years). In addition, the cost of maintaining the bureaucracy (government issues) grew faster in the capital, which looks strange in the context of the economic crisis.

The remaining regions chose different priorities. In almost $80 \%$ of federal subjects, expenditures on housing and communal services have increased to subsidize public utilities from the budget. In this way, the authorities tried to restrain growth of housing and communal services fees in the face of declining disposable incomes. Almost all regions have increased spending on built environment to meet the indicators developed by the federal authorities for the national project. Only nine regions have reduced spending on the national economy, mainly by reducing support for the agricultural sector and public transport. The rest increased expenses for implementation of national projects, especially for road construction, including regions with a strong drop in their own budget revenues (Yamalo-Nenets Autonomous Okrug, the republics of Komi and Bashkortostan; and Tyumen, Arkhangelsk, and Astrakhan oblasts). On the whole, the "corridor of opportunities" for regions in spending maneuver has narrowed due to the prevalence of targeted transfers to their budgets.

6. Despite the More than 1.5-Fold Increase in Aid, the Balance of Regional Budgets in 2020 Deteriorated due to the Need to Rapidly Increase Social Spending, so Most Regions Had Budget Deficits. Its Scale Is Comparable to the 2009 Crisis, But Less Than in the Mid-2010s, during the Period of Execution of Decrees on Wage Increase

Faster spendings growth in $2020(+15 \%)$ versus revenues $(+10 \%)$ led to a deficit in regional budgets, which amounted to almost $5 \%$ of revenues. The year ended with a deficit in 57 regions. In 2019, there were 35 ; in 2018, only 15 (Fig. 3). The most deficient are the budgets of regions with large revenue losses and weak or insufficient federal aid: Tyumen and Kemerovo oblasts (-20 to $-21 \%$ in 2020); Yamalo-Nenets Autonomous Okrug; the republics of Bashkortostan, Komi, Udmurtia, and Khakassia; Perm Krai; and Arkhangelsk and Tomsk Oblasts ( -12 to $-16 \%)$. Of these, only Khakassia and Arkhangelsk Oblast are classified as medium-subsidized, the rest are low-subsidized. Thus, the deficit problem is more acute in regions that were less dependent on federal aid.

The budget deficit of regions in the pandemic is large, but not unique. During the 2009 crisis, more than 50 regions had budget deficits, and the deficit level was comparable: $5.5 \%$ of revenues. The most severe deficit was associated not with crises, but with 


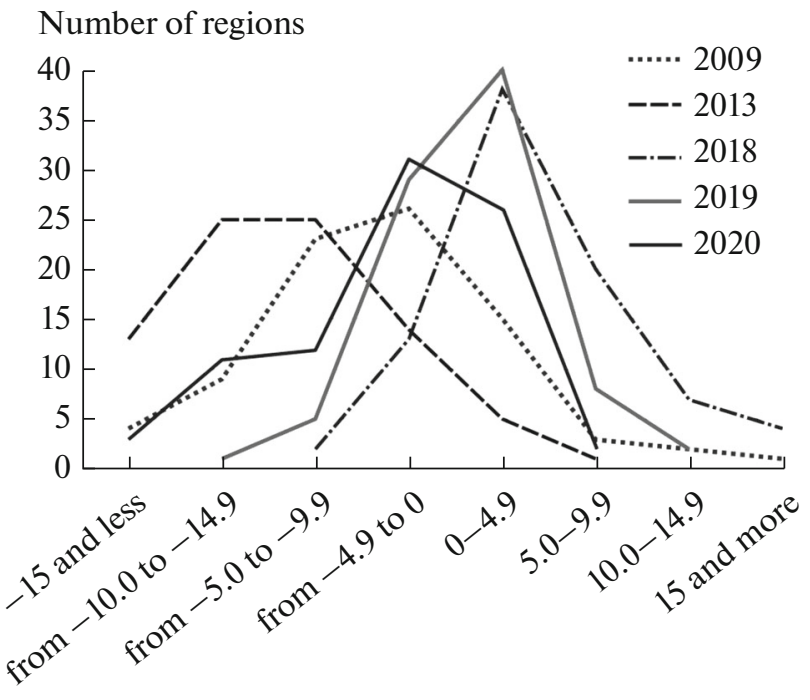

Fig. 3. Distribution of regions by deficit/surplus of consolidated budget, in $\%$ of budget revenues.

the implementation of decrees on wage increase, which were financed mainly from regional budgets. In 2013-2015, the overwhelming majority of regions experienced this: the level of deficit reached $7-8 \%$ of budget revenues. Problems of unbalanced budgets haunted regions for almost all the 2010s, which has increased their dependence on federal aid and budget loans.

The budget deficit in 2020 led to an increase in the debt of regions and municipalities, which in 2020 increased from RUB 2.4 to $2.8 \mathrm{trln}$. The debt burden in most regions was high even before the pandemic (most was accumulated during the years of implementation of decrees on wage increase), but it still declined in 2018-2019. The growth of debt in the pandemic will inevitably lead to the RF Ministry of Finance tightening control over the expenses of the most heavily indebted regions and to a further centralization of regional budget management.

\section{CONCLUSIONS}

The analysis allows the following conclusions that refute arguments about the shift towards decentralization or even federalization in Russia in 2020.

In the year of the pandemic, aid to regional budgets increased unprecedentedly, which made it possible to fulfill the year with positive revenue dynamics in most regions, but it led to a significant increase in the dependence of budgets on federal aid (transfers).

In the structure of aid, the share of targeted transfers sharply increased, so the ability to maneuver budget resources for regions has decreased; they have been forced to spend additional funds mainly on goals prescribed from above, which has led to a further increase in centralization of management.
The transparency of the allocation of transfers to regions has worsened: it is impossible to explain the differences in the amount of aid to regions that have greatly lost their own revenue or those that have not lost any. Whereas before the pandemic there were high-priority "geopolitical" regions (Crimea, Sevastopol, Chechnya, Dagestan, and, partly, Far Eastern regions) that received more significant assistance, in 2020 it is much more difficult to explain the results of the decisions of various federal agencies on allocation of transfers to federal subjects.

Fiscal federalism in Russia was noticeable only in the choice of spending priorities, but in the year of COVID, it became less and less. The common priority was healthcare and, almost everywhere, social security; for these purposes, regions received significantly greater transfers. In other expenditures, most regions either subsidized utility fees or tried to fulfill numerous targets of presidential decrees (road construction, built environment improvement, various social indicators).

Thus, the expectations and hopes for decentralization of the Russian system of government during the pandemic were not realized; in interbudgetary relations, the degree of dependence of regions on the federal authorities only increased. The main conclusion is that verbal declarations do not correspond to reality when checked against actual monies.

\section{CONFLICT OF INTEREST}

The author declares no conflict of interest.

\section{REFERENCES}

Bennett, R.J., The Geography of Public Finance: Welfare under Fiscal Federalism and Local Government Finance, London: Methuen, 1980.

Bouckaert, G., Galli, D., Kulhmann, S., Reiter, R., and van Hecke, S., European coronationalism? A hot spot governing a pandemic crisis, Publ. Admin. Rev., 2020, vol. 80 , no. 5 , pp. $765-773$.

https://doi.org/10.1111/puar.13242

Boyne, G. and Powell, M., Territorial justice: a review of theory and evidence, Polit. Geogr. Q., 1991, vol. 10, no. 3, pp. 263-281.

Chernyavsky, A., Virus in the regions, Kommentarii Gos. Biz., 2020a, no. 291. https://www.hse.ru/pubs/share/direct/document/373271455.pdf.

Chernyavsky, A., Outstanding spendings and growth of regional imbalance during a pandemic, Kommentarii Gos. Biz., 2020b, no. 308. https://www.hse.ru/pubs/share/direct/document/446644357.pdf.

Chernyavsky, A., COVID in the regions, Kommentarii Gos. Biz., 2021, no. 345. https://www.hse.ru/pubs/share/direct/document/392007105.pdf.

Deryugin, A.N., Regional budgets in January-May 2020: federal financial transfers stabilize the situation, Ekon. Razvit. Ross., 2020a, no. 7, pp. 112-115. 
Deryugin, A.N., Regional budgets in crisis conditions, Ekon. Razvit. Ross., 2020b, no. 12, pp. 74-77.

Finta, I., Kovács, K., and Pálné Kovács, I., The Role of Local Governments in Control the Pandemic in Hungary: IGU Commission Geography of Governance Working Paper No. 2, IGU Com. Geogr. Governance, 2020. https://sites.google.com/view/igucgog-covid19/working-papers

Franzke, J., German Municipalities in the COVID-19 Pandemic Crisis. Challenges and Adjustments. A Preliminary Analysis: IGU Commission Geography of Governance Working Paper No. 1, IGU Com. Geogr. Governance, 2020. https://sites.google.com/view/igucgogcovid19/working-papers

Gore, T., Bimpson, E., Dobson, J., and Parkes, S., Local Government Responses to the COVID-19 Pandemic in the UK: A Thematic Review: IGU Commission Geography of Governance Working Paper No. 3, Sheffield: Centre Reg. Econ. Soc. Res., 2021. https://sites.google.com/view/igucgog-covid19/working-papers

Khasanova, R.R. and Zubarevich, N.V., Fertility, mortality, and the position of the regions at the beginning of the second wave of the pandemic, Ekon. Razvit. Ross., 2021, no. 1, pp. 77-87.

Khasanova, R.R., Florinskaya, Yu.F., Zubarevich, N.V., and Burdyak, A.Ya., Demographic and socioeconomic regional indicators in April 2020 (according to regular monitoring of the Institute for Social Analysis and Forecasting), Ekon. Razvit. Ross., 2020, no. 6, pp. 80-100.
Kuznetsova, O.V., Regional budgets and interbudgetary relations during the crisis, Reg. Issled., 2010, no. 2, pp. 32-41.

Makarentseva, A.O., Mkrtchyan, N.V., and Zubarevich, N.V., Demographic situation and socioeconomic development of Russian regions in the first half of 2020, Ekon. Razvit. Ross., 2020, no. 10, pp. 73-88.

Mil'chakov, M.V., Implementation of national projects in the regions in the context of countering coronavirus pandemic, Fin. Zh., 2020, vol. 12, no. 3, pp. 28-47.

Starodubovskaya, I.V., Zubarevich, N.V., Nazarov, V.S., and Gorina, E.A., Analiz regional'noi antikrizisnoi politiki (Analysis of Regional Anti-Crisis Policy), Moscow: Ross. Akad. Nar. Khoz. Gos. Sluzhby, 2010.

Zubarevich, N.V., Russian regions: challenges of crisis and modernization, in Rossiiskie regiony: ekonomicheskii krizis i problemy modernizatsii (Russian Regions: Economic Crisis and Modernization Problems), Moscow: TEIS, 2011, pp. 122-138.

Zubarevich, N.V., Regional projection of the new Russian crisis, Vopr. Ekon., 2015, no. 4, pp. 37-52.

Zubarevich, N.V. and Gorina, E.A., Sotsial'nye raskhody $v$ Rossii: federal'nyi $i$ regional'nye byudzhety (Social Spendings in Russia: Federal and Regional Budgets), Moscow: Nats. Issled. Univ. Vyssh. Shk. Ekon., 2015.

Zubarevich, N.V. and Safronov, S.G., Russian regions in the acute phase of the coronavirus crisis: differences from previous economic crises of the 2000s, Reg. Res. Russ., 2020, vol. 10, no. 4, pp. 443-453. 